\title{
PENGARUH AKTUALISASI DIRI TERHADAP MOTIVASI BERPRESTASI KARYAWAN PT.WIRA KARYA SAKTI JAMBI
}

\author{
Ahmad Tarmizi \\ Fakultas Ekonomi Universitas Batanghari Jambi \\ tarmizi_fe@yahoo.co.id
}

\begin{abstract}
Many theories explain the achievement motivation is influenced by self actualization factor. This research investigates the influence of self actualization to achievement motivation. Data was collected using questionnaires and utilizing purposive non random sampling technique with 56 respondents. Anava Rambang Lugas is used to test the hypothesis. The result shows FoA (6,560) > F-tabel 5\% (4.03) which means there is significant influence of self actualization to achievement motivation at PT WKS employee.
\end{abstract}

\section{Key words: achievement, motivation, self actualization}

Semua individu mempunyai keinginan untuk mencapai apa yang dicitacitakan. Dengan adanya cita-cita inilah maka kebutuhan untuk berprestasi dimiliki setiap individu. Setiap orang ingin dipandang sebagai orang yang berhasil dalam hidupnya, keberhasilan itu bahkan mencakup seluruh segi kehidupan dan penghidupan seseorang baik itu keberhasilan dalam dunia kerja, keberhasilan dalam membina rumah tangga bahagia, keberhasilan dalam usaha dan keberhasilan dalam bidang-bidang kehidupan lainnya (Mc Clelland dalam Siagian, 1989:168)

Adanya suatu konsep bahwa tiap-tiap individu mempunyai kebutuhan untuk berprestasi yang mana kebutuhan berprestasi tersebut adalah untuk memenuhi tujuan hidupnya, maka tidak bias dihindarkan lagi apabila ada persaingan di dalamnya, karena tiap-tiap individu menginginkan agar segala tujuannya tercapai.

Menurut Gibson ,Ivancevich dan Donnelly menyatakan bahwa motif tertinggi manusia adalah mengembangkan kapasitas atau potensi-potensinya setinggi mungkin. Sebagai syarat bagi kelancaran dalam meraih prestasi yang motivasi adalah suatu variabel penyelang yang digunakan untuk menimbulkan faktor-faktor tertentu didalam organisme, yang membangkitkan, mengelola, 
mempertahankan dan menyalurkan tingkah laku tinggi maka fungsi motivasi atau dorongan sangat diperlukan, sebab dengan adanya motivasi maka prestasi bisa berkembang dan kesuksesan bisa diraih sesuai dengan yang direncanakan.

T Hani Handoko (1995) menjelaskan bahwa motivasi atau dorongan adalah sesuatu pernyataan yang kompleks di dalam suatu organisme yang mengarahkan tingkah laku terhadap tujuan perangsang. Dengan demikian dapat diketahui bahwa makin jelas tujuan yang diharapkan atau yang akan dicapai makin jelas pula bagaimana tindakan memotivasi itu dilakukan.

Seperti halnya dengan dorongan berprestasi (achievement motive) yang kemunculannya dipengaruhi oleh salah satu aspek karakterologis. Dalam batasbatas tertentu dorongan berprestasi adalah suatu yang ada yang menjadi ciri dari kepribadian seseorang, sesuatu yang mengenai apa yang ada dan dibawa sejak lahir. Namun dipihak lain dorongan berprestasi ternyata dalam banyak hal adalah sesuatu yang ditumbuhkan, dikembangkan, hasil dari mempelajari melalui interaksi dengan lingkungan (Singgih, 1995:139).

Prestasi merupakan hasil pekerjaan atau apa saja yang telah diciptakan atau hasil yang menyenangkan hati yang diperoleh dengan jalan hasil keuletan kerja (Suryabrata, 1981:7). Sedangkan motivasi berprestasi menurut Lindgren dan Murray adalah dorongan yang berhubungan dengan prestasi yaitu kebutuhan untuk menguasai, manipulasi dan mengatur lingkungan social maupun fisik, mengatasi rintangan-rintangan dan memelihara kualitas kerja yang tinggi, bersaing melalui usaha-usaha untuk melebihi pekerjaannya yang lampau dan mengungguli orang lain (Adam,1989).

Tujuan penelitian ini untuk mengetahui apakah ada pengaruh antara aktualisasi diri terhadap motivasi berprestasi karyawan PT.Wira Karya Sakti.

\section{METODE}

\section{Populasi dan sampel}

Populasi adalah jumlah dari keseluruhan subyek yang karakteristiknya hendak diduga. Sample adalah sebagian dari populasi yang karateristiknya hendak diselidiki dan dianggap bias mewakili keseluruhan populasi. 
Populasi yang akan digunakan adalah karyawan PT.Wira Karya Sakti. Sedangkan sample yang diambil sebanyak 56 responden, teknik pengambilan sample dilakukan dengan menggunakan purposive non random sampling.

\section{Teknik pengambilan data}

Teknik pengambilan data adalah angket. Angket sebagai alat atau teknik pengambilan data degan ciri khas bahwa didalamnya terdapat berbagai pernyataan atau pertanyaan yang disusun secara tertulis dengan apa yang hendak diteliti. Adapun cara penilaiannya masing-masing item tergantung pada sifat item itu sendiri. Item yang bersifat favorable adalah item yang memuat pertanyaan yang mendukung atau memiliki arah positif, sedangkan item yang unfavorable adalah item yang memuat pernyataan tidak mendukung atau memiliki arah negatif. Dengan angket sebagai berikut :

Pernyataan yang favourable Pertanyaan yang unfavourable

Untuk jawaban SS diberi nilai 4 Untuk jawaban SS diberi nilai 1

Untuk jawaban S diberi nilai 3 Untuk jawaban $S$ diberi nilai 2

Untuk jawaban TS diberi nilai 2 Untuk jawaban TS diberi nilai 3 Untuk jawban STS diberi nilai 1 Untuk jawban STS diberi nilai 4

\section{Validitas dan reliabilitas}

Validitas adalah indeks yang menunjukkan sejauh mana suatu alat ukur betul-betul mengukur apa yang ingin diukur (Suryabrata, 1993:29). Rumus yang digunakan untuk mencari validitas adalah dengan menggunakan teknik korelasi product moment dari karl person dengan rumus sebagai berikut :

$$
r x y=\frac{N \cdot \Sigma x y-(\Sigma x)(\Sigma y)}{\sqrt{ }\left[\mathrm{N} \cdot \Sigma \mathrm{x}^{2}-(\Sigma \mathrm{x})^{2}\right]\left[\mathrm{N} \cdot \Sigma \mathrm{y}^{2}-(\Sigma \mathrm{y})^{2}\right]}
$$

\section{Keterangan:}

rxy = korelasi product moment antara variable $\mathrm{x}$ dan $\mathrm{y}$

$\mathrm{N}$ : Jumlah subyek dalam penelitian

$\Sigma x \quad$ : jumlah variable $\mathrm{x}$

$\Sigma y \quad$ : jumlah variable y

$\Sigma x y \quad$ : jumlah perkalian variable $\mathrm{x}$ dan $\mathrm{y}$

$\Sigma x^{2} \quad$ : jumlah kuadrad skor item

$\Sigma y^{2} \quad$ : jumlah kuadrad skor total 
Untuk menentukan valid tidaknya item yang dibuat, digunakan kriteria penerimaan atau penolakan validitas item sebagai berikut :

- Jika angka korelasi yang diperoleh nilainya lebih kecil dari r-teoritik pada taraf signifikan $(0,05)$ atau $(0,01)$ maka item dinyatakan tidak valid.

- Jika angka korelasi yang diperoleh nilainya lebih besar dari r-teoritik pada taraf sgnifikan $(0,05)$ atau $(0,01)$ maka item dinyatakan valid.

\section{Reliabilitas}

Reliabilitas suatu alat ukur menunjukkan taraf sejauh mana alat ukur itu sama dengan dirinya sendiri atau dapat dikatakan bahwa reliabilitas tes/alat ukur itu menunjukkan keajegan suatu tes (Suryabrata, 1993:29). Untuk mengetahui reliabilitas maka digunakan tehnik ukur daro Spearman-Brown. Tinggi rendahnya reliabilitas alat ukur/tes yang dibuat ditentukan oleh besarnya koefisien korelasi yang diperolah berdasarkan perhitungan dengan menggunakan rumus diatas. Makin tinggi koefisien korelasi antara dua belahan, maka makin tinggi koefisien reliabilitasnya.

Dalam menentukan apabila alat ukur angket yang telah dibuat reliable atau tidak maka didasarkan dengan ketentuan sebagai berikut:

- Jika angka korelasi yang diperoleh nilainya lebih kecil dari r-tabel pada taraf signifikan $(5 \%=0,254)$ atau $(1 \%=0,330)$ maka angket dinyatakan tidak reliable.

- Jika angka korelasi yang diperoleh nilainya sama atau lebih besar dari rtabel pada taraf signifikan $(5 \%=0,254)$ atau $(1 \%=0,330)$ maka angket dinyatakan reliable (Hadi, 1993:302).

\section{Metode Analisa Data}

Penelitian ini ditujukan untuk menguji kebenaran suatu dugaan yang diakui sebelum penelitian. Dugaan ini dapat terbukti kebenarannya maupun tidak terbukti kebenarannya. Jika suatu dugaan terbukti kebenarannya maka hasilnya akan diterima dan jika dugaan tidak terbukti kebenarannya maka hasilnya tidak dapat diterima. Untuk menganalisa data terkumpul dari data penelitian, digunakan analisa statistik. Analisa data tersebut dimaksudkan untuk membuktikan hipotesa yang dibuat dalam penelitian ini yang menyatakan bahwa : Ada pengaruh aktualisasi diri terhadap motivasi berprestasi. Untuk 
mengetahui ada tidaknya pengaruh aktualisasi diri terhadap motivasi berprestasi maka digunakan rancangan rambang lugas.

\section{Analisa Rambang Lugas}

Dalam penelitian ini menggunakan rancangan rambang lugas. Adapun langkahlangkah dari rancangan ini secara berturut-turut yaitu:

Rancangan rumus Analisa Rambang Lugas

$\mathrm{FoA}=\underline{\mathrm{MKA}}=\mathrm{dbFoA}=\mathrm{dbA} / \mathrm{dbd}$ MKd

Dimana :

a : jumlah perlakuan

n : jumlah subyek dalam kelompok

$\mathrm{N} \quad$ : jumlah subyek seluruhnya

Fo : Harga F yang diperoleh

1. Tabel komputasi

Criterion score

\begin{tabular}{lc}
$\mathrm{A} 1$ & $\mathrm{~A} 2$ \\
\hline $\mathrm{X} 1$ & $\mathrm{X} 1$ \\
$\mathrm{X} 2$ & $\mathrm{X} 2$ \\
$\ldots \ldots$ & $\ldots \ldots \ldots$ \\
$\mathrm{Xn}$ & $\mathrm{Xn}$
\end{tabular}

Keterangan :

A1 : Aktualisasi diri tinggi

A2 : Aktualisasi diri tinggi

$X$ : Motivasi Berprestasi

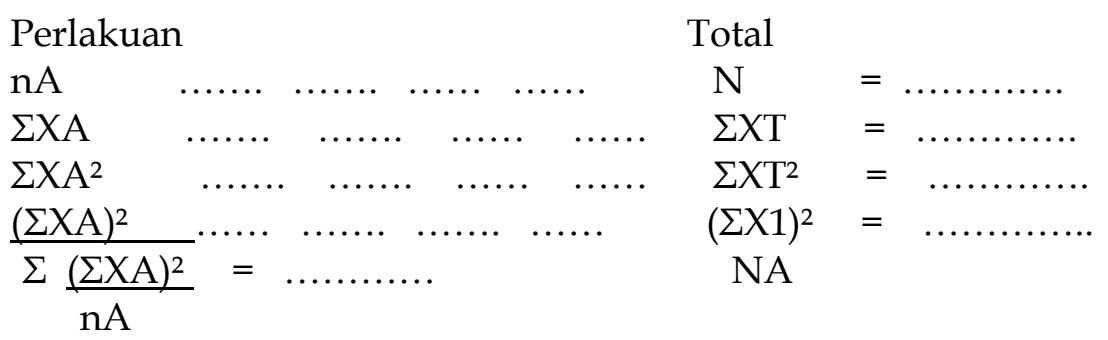

Cara-cara komputasi berikut :

Komputasi dapat dilakukan melalui langkah-langkah baru sebagai

1. JKT $=\Sigma X^{2} \mathrm{~T}-\frac{(\Sigma X \mathrm{t})^{2}}{\mathrm{~N}}=$

2. JKA $=\underline{\Sigma(X A)^{2}}-\underline{(\Sigma X T)^{2}}=$ 
3. JKD = JKT-JKA $=$

4. $\mathrm{dbA}=\mathrm{a}-1=$

5. $\mathrm{dbb}=\mathrm{N}-\mathrm{a}=$

6. $\mathrm{dbt}=\mathrm{N}-1=$

7. $\mathrm{MKA}=\mathrm{JKA}: \mathrm{dbA}=$

8. $\mathrm{MKd}=\mathrm{JKd}: \mathrm{dbd}=$

9. Membuat table rangkuman atau table ringkasan analisa varians dari pekerjaan-pekerjaan komputasi yang telah diselesaikan.

10. FoA = MKA : MKd =

11. $\mathrm{db}$ FoA $=$ dbA lawan dbd $=$

Keterangan :

$\begin{array}{ll}\mathrm{a} & \text { : Jumlah perlakuan } \\ \mathrm{n} & \text { : Jumlah subyek dalam kelompok } \\ \mathrm{N} & \text { : Jumlah subyek seluruhnya } \\ \mathrm{FO} & \text { : Harga F yag diperoleh } \\ \mathrm{Db} & \text { : derajad kebebasan } \\ \mathrm{MK} & \text { : Mean kuadrad } \\ \mathrm{JK} & \text { : Jumlah kuadrad }\end{array}$

Cara pengambilan keputusan

Pengambilan keputusan dilaksanakan menurut aturan keputusan yang telah ditetapkan:

a. Harga F tidak signifikan jika FoA $<$ F table 5\%, sehingga hipotesa alternatif ditolak.

Kesimpulan : bahwa antara perlakuan yang satu tidak ada perbedaan efek yang signifikan dengan perlakuan yang lainnya. Ditulis dengan lambing $\mathrm{p}>0,05$.

b. Harga FoA dippandang signifikan jika FoA > Ftabel 5\%, dan hipotesa alternatif tidak ditolak.

Kesimpulan : Ada perbedaan efek yang signifikan antara perlakuan yang satu dengan yang lainnya. Ditulis dengan lambang $p<5 \%$.

c. Harga FoA dikatakan sangat signifikan sekitar FoA > Ftabel 1\% dan hipotesa alternatif sangat diterima.

Kesimpulan : bahwa efek perlakuan yang satu dengan yang lain berbeda secara signifikan. Ditulis dengan lambing $\mathrm{p}<0,01$.

Cara rancangan rambang lugas ini digunakan apabila pengambilan anggota sampel dilakukan secara langsung tanpa syarat dari populasi induknya. 
Selain itu untuk lebih jelasnya maka dijelaskan tentang asumsi-asumsi daripada ANAVA. Seperti juga dalam tiap-tiap pengetesan statistik, pengetesan dengan F-test ini juga menggunakan asumsi-asumsi teori tertentu. Ada tiga macam asumsi yang perlu diindahkan dalam penggunaan teknik ANAVA yaitu:

1. Bahwa subyek-subyek/individu-indnvidu yang ditugaskan dalam sampelsampel penyelidikan harus diambil secara random.

2. Bahwa distribusi gejala yang diselidiki dalam masing-masing populasi itu adalah normal.

3. Bahwa varians-varians atau $\mathrm{SD}^{2}$ dari masing-masing populasi tidak menunjukkan perbedaan yang signifikan satu sama lain.

\section{HASIL DAN PEMBAHASAN}

\section{Hasil}

Persiapan perhitungan rambang lugas:

\begin{tabular}{|l|l|l|l|}
\hline & A1 & A2 & Jumlah \\
\hline $\mathrm{N}$ & 27 & 29 & 56 \\
$\mathrm{X}$ & 5038 & 5163 & 10201 \\
Rata $^{2}(\mathrm{X})$ & 186,592592 & 178,03448 & 377,814814 \\
$\mathrm{X} 2$ & 943956 & 923875 & 1867831 \\
\hline
\end{tabular}

Berdasarkan table tersebut maka dilakukan perhitungan untuk membuat tabel ringkasan ANAVA yaitu dengan menghitung :

- Jumlah kuadrad total (JKT)

- Jumlah kuadrad antara (KJA)

- Jumlah kuadrad dalam (JKd)

Sedangkan langkah-langkah perhitungannya adalah sebagai berikut :

Langkah 1. Menghitung Kuadrad Total (JKT)

$$
\begin{aligned}
\mathrm{JKT} & =\Sigma \mathrm{X}^{2} \mathrm{~A} 1+\Sigma \mathrm{X}^{2} \mathrm{~A} 2-\frac{(\Sigma \mathrm{XT})}{\mathrm{NT}} \\
& =943956+923875-\frac{(10201)^{2}}{56} \\
& =1867831-\frac{104060401}{56} \\
& =1867831-1858221,446 \\
& =9609,554
\end{aligned}
$$

Langkah 2. Menghitung jumlah kuadrad Antara (JKA) 


$$
\begin{aligned}
\mathrm{JKT} & =\frac{\Sigma \mathrm{X}^{2} \mathrm{~A} 1}{\mathrm{NA} 1}+\frac{\Sigma \mathrm{XA} 2^{2}}{\mathrm{NA2}}-\frac{(\Sigma \mathrm{XT})^{2}}{\mathrm{NT}} \\
& =\frac{(5038) 2}{27}+\frac{(5163) 2}{29}-\frac{(10201) 2}{56} \\
& =\frac{25381444}{27}+\frac{26656569}{29}-\frac{104060401}{56} \\
& =940053,4815+919192,0345-1858221,446 \\
& =1858245,516-1858221,446 \\
& =1024,0699
\end{aligned}
$$

Langkah 3. Menghitung jumlah kuadrad dalam (JKd)

$$
\begin{aligned}
\mathrm{JKd} & =\mathrm{JKT}-\mathrm{JKA} \\
& =9609,554-1024,0699 \\
& =8585,4841
\end{aligned}
$$

Langkah 4. Menghitung Derajad kebebasan untuk masing-masing sumber variasi $(\mathrm{db})$

$$
\begin{aligned}
\mathrm{dbA} & =\text { Banyaknya perlakuan } \mathrm{A}(\mathrm{A} 1, \mathrm{~A} 2)-1 \\
& =2-1 \\
& =1 \\
\mathrm{dbd} & =\mathrm{N}- \\
& =56-2 \\
& =54 \\
\mathrm{dbT} & =\mathrm{N}-1 \\
& =56-1 \\
& =55
\end{aligned}
$$

Langkah 5. Menghitung Mean Kuadrad (MK)

$$
\begin{aligned}
\text { MKA } & =\underline{\mathrm{JKA}} \\
& =\underline{1024,0699} \\
& =1024,0699 \\
& =\frac{\mathrm{K} \mathrm{d}}{\mathrm{Dbd}} \\
& =\frac{8585,4841}{5 \mathrm{5} d} \\
& =156,0997109
\end{aligned}
$$

Langkah 6. Menghitung harga Fo

$$
\begin{aligned}
\text { FoA } & =\underline{M K A} \\
& =\underline{M K d}
\end{aligned}
$$




$$
\begin{gathered}
156,0997109 \\
=\quad 6,560357
\end{gathered}
$$

Langkah 7. Membandingkan setiap nilai Fo yang diperoleh dengan nilai F-tabel Dalam hal mengkonsultasikan dengan nilai F-tabel maka dbF adalah dbA lawan $\mathrm{dbd}$, dengan demikian $\mathrm{dbF}=1$ lawan 54 .

- Untuk taraf signifikan 5\% F-tabel $=4,03$

- $\quad$ Untuk taraf signifikan $1 \%$ F-tabel $=7,17$

Dengan demikian dapat ditarik kesimpulan :

- $\quad$ FoA $(5,560)>$ F-tabel $(4,03)$ signifikan pada taraf signifikan 5\%

- FoA $(6,560)<$ F-tabel $(7,17)$ sangat signifikan pada taraf signifikan $1 \%$

Langkah 8. Memasukkan nilai-nilai yang sudah diperoleh ke dalam tabel ringkasan ANAVA

Tabel Ringkasan ANAVA

\begin{tabular}{|l|l|l|l|l|l|}
\hline $\begin{array}{l}\text { Sumber } \\
\text { variasi }\end{array}$ & $\mathrm{JK}$ & $\mathrm{db}$ & $\mathrm{MK}$ & Fo & $\mathrm{P}$ \\
\hline A & 1024,0699 & 1 & 1024,0699 & 6,560 & $<0,05$ \\
\hline Dalam & 8585,4841 & 54 & 156,0997 & - & - \\
\hline Total & 9609,554 & 55 & - & - & - \\
\hline
\end{tabular}

Langkah 9. Menarik kesimpulan

Karena F-hitung $(6,560)>$ F-tabel 5\% $(4,03)$ dan F-hitung $(6,560)<$ F-tabel $1 \%(7,17)$ maka hipotesa alternative yang diajukan diterima. Hal ini berarti pernyataan : “Ada Pengaruh Aktualisasi Diri Terhadap Motivasi Berprestasi Karyawan PT. WKS", Diterima pada taraf signifikan 5\%.

\section{Pembahasan}

Dari hasil penelitian yang dilakukan dan setelah melalui analisis varian (rambang lugas) maka didapatkan hasil : "Ada Pengaruh Aktualisasi Diri Terhadap Motivasi Berprestasi Karyawan PT. WKS".

Berdasarkan hasil penelitian dapat diartikan bahwa aktualisasi diri mempunyai pengaruh terhadap motivasi berprestasi karyawan PT.WKS dalam hal ini pegawainya. Aktualisasi diri sangat berarti bagi individu sehingga akan membuat individu tersebut mempunyai dorongan untuk mengembangkan prestasinya di dalam suatu pekerjaan. 
Aktualisasi diri merupakan salah satu aspek psikis manusia yang sangat penting ntuk dikembangkan. Lauster (dalam Saleh,1992:6) menjelaskan bahwa Aktualisasi mengandung arti adanya sikap yakin akan kemampuan diri, karena tidak akan gampang terpengaruh oleh orang lain.

Individu yang percaya akan kemampuan diri maka keinginannya untuk meraih dan mewujudkan cita-citanya akan tinggi. Dengan adanya keinginan untuk meraih dan mewujudkan cita-cita inilah maka kebutuhan untuk berprestasi akan dimiliki oleh setiap individu.

Sebagai syarat bagi kelancaran dalam meraih cita-cita inilah maka fungsi dorongan atau motivasi sangat diperlukan sebab dengan adanya motivasi ini maka harapan berprestasi semakin berkembang dan cita-cita akan bisa diraih sesuai dengan yang direncanakan.

Dengan demikian dapat dikatakan bahwa aktualisasi diri merupakan suatu aspek yang berguna yang seharusnya dimiliki oleh setiap individu dalam menghadapi masalah yang dihadapi dalam kehidupan sehari-hari. Selain itu aktualisasi diri dibutuhkan untuk mengembangkan diri dalam meraih citacitanya. Sebab dengan adanya aktualisasi diri dalam diri individu maka semangat atau dorongan untuk berprestasi semakin deras atau tinggi.

\section{KESIMPULAN}

Berdasarkan hasil penelitian hipotesa alternatif yang menyatakanbahwa ada pengaruh aktualisasi diri terhadap motivasi berprestasi karyawan PT.WKS yang diajukan diterima pada taraf signfikansi 5\%. Sehingga dapat diartikan bahwa aktualisasi diri mempunyai pengaruh terhadap motivasi berprestasi karyawan PT.WKS dalam hal ini pegawainya. Aktualisasi diri sangat berarti bagi individu sehingga akan membuat individu tersebut mempunyai dorongan untuk mengembangkan prestasinya di dalam suatu pekerjaan.

\section{DAFTAR PUSTAKA}

Adam, I. 1989. Perilaku Organisasi. Bandung: Penerbit Sinar Baru.

Donnelly, Ivancevich Gibson. 1996. Organisasi, Perilaku, Struktur,Proses. Edisi kedelapan. Jakarta: Binarupa Aksara. 
Handoko Hani T. 1995. Manajemen Personalia dan Sumberdaya Manusia. Edisi 2. BPFE.

Siagian, P.Sondang. 1989. Teori Motivasi dan Aplikasinya. Jakarta: Bina Aksara.

Suryabrata, Sumadi. !981. Panduan Seri Program Statistik. Yogyakarta UGM.

Sayles D R Leonar, Goerge Strauss. 1996. Manajemen Personalia, Jilid 1. Jakarta: Pustaka Binaman Pressindo. 